\title{
Legislative and Executive Conflicts in Nigeria's Presidential Democracy since the Fourth Republic (1999-2021)
}

\author{
Kunle Awotokun ${ }^{1}$ \\ ${ }^{1}$ Obafemi Awolowo University, Ile-Ife, Osun State, Nigeria \\ Correspondence: Prof. Kunle Awotokun, 3721 Chandler Dr NE, Apt 203, Minneapolis MN 55421-4449, United States.
}

Received: February 15, 2021

doi:10.11114/ijsss.v10i2.5457
Accepted: March 22, $2021 \quad$ Available online: January 21, 2022

URL: https://doi.org/10.11114/ijsss.v10i2.5457

\begin{abstract}
The work examines the legislative-executive conflicts in Nigeria's presidential democracy in an exploratory manner since the inception of Nigeria's fourth republic to date. The paper also undertake the study of the processes of the two (legislative and executive) arms in order to determine and interrogate the issues involved in their differences.

The work relies mainly on secondary data to elicite information and to run analysis for the discourse. Such data includes textbooks, journals, periodicals, news magazines, newspapers, etc.

The findings are that the relationships between the legislative and executive have not been all that cordial since the inauguration of Nigeria's fourth republic. It is also discovered that political party differences, regional, ethnic and religious affiliations have fueled the differences.

The work concludes on a note of recommendations that there is a serious need for review of the 1999 constitution with the view of granting autonomy to the constituent units that make up the Nigerian state. The works also contextualizes the need for mutual respect, and underscore the sanctity of legislative and executive institutions as critical stakeholders in good governance.
\end{abstract}

Keywords: legislative, executive, conflict, presidential, democracy

\section{Introduction}

There has been a noticeable trend of institutional conflicts between the legislature and executive arms of government since the inception of Nigeria's fourth republic in 1999. This altercation has for quite sometimes become a challenge for good governance, as the legislative and executive arms are critical institutions for the advancement of democracy. It is against this backdrop that the work seeks for curtailment (if not total elimination) of the perennial conflicts which if unrestrained can compromise (violate) the ideal of constitutional democracy.

The work has therefore set to explore and analyse different mechanisms of the conflict resolution in order to ameliorate the problem between the two arms of government. The paper will also review the legislative and executive processes during the period in question in order to garner the much necessary information about the internal dynamics between the two (the legislative and executive) arms of government. It is for this reason that this work will briefly analyse the intent of presidential democracy as a panacea for meeting one of the set goals in this discourse.

\section{The Presidential Democracy in Nigeria Setting}

The Nigeria's presidential democracy (unlike the parliamentary system) is based essentially on a tripartite system of government namely legislature, executive and judiciary. The legislature is regarded as the very essence of representative democracy, as they are regarded as accredited representatives of the people. They make laws for good governance and orderliness of the society. The executive which is normally vested in a single caste of president or governor with its cabinet, execute the laws, formulate and implement policies, subject to legislative approval in most cases.

The Nigerian 1999 Constitution, expects institutional independence of the legislative and executive arms of government, howbeit, with a measure of cooperation and interdependence in order to foster amicable working relationship that will deliver the dividends of democracy to all and sundry. However, in carrying out the legislative-executive assignments, there is conflict of interests which may either be deliberate or due to lack of constitutional interpretations. When such situation arises, it is the duty of the judiciary as an umpire to interpret, mediate and reconcile the issue between the 
legislature and the executive.

It must be stated from the outset that the work has not set out to analyse the judicial interpretations of the conflicts between the legislature and the executive. The work is essentially based on the legislative-executive conflicts identified over a period of time (1999-2020) and how we can stem the tide of such conflicts in future as a panacea (catholicon) for engendering an enduring political system.

As a pathway to understanding the contextual and theoretical basis of this work, there is the need to briefly provide a framework of legislative-executive relations in a presidential system of government. Other conceptual issue that is germane to it, perhaps, is the models of legislative-executive relations as well as the typology of legislative-executive relations. These and other issues are what the work will address shortly.

\section{Legislative-Executive Relations}

Certain concepts are germane for a proper understanding of legislative-executive relationship in a presidential system of government. These concepts are the theory of separation of power which denotes a separation of the processes, and power within the government along functional lines. Government consists of three-fold activities - law making, law enforcement and law adjudication, each performed by a separate institution, with equal legitimate authority and independent base of support. This concept is misleading. No such clear-cut division of functions exists or can be expected to exist. There are some levels of intermingling and cooperation of functions by the co-ordinate branches, which itself is necessary for proper governance. As Madison argued in the federalist paper: "unless these departments be so far connected and blended as to give each other a constitution, which the maxim requires, a free government can never in practice be duly maintained".

Akin to this concept is that of checks and balances. It had been defined as: One branch thwarting hampering, interfering, with criticizing and opposing the activities of the other, so as to counteract the wisdom of the wise.

The concept states that each arm of government should check, control and watch the other so as to stop misuse of power. These two concepts distinguish the presidential system of government and create the framework with which to understand its legislative-executive relationship. The executive, legislative and judiciary are separate, independent and self-existing, and all derive their powers from the constitution. Neither the executive nor the legislature is continuously dependent on the other for its survival. All are given powers to influence and check the other.

The executive has veto power over the legislature, confirms executive appointments and could impeach the executive. The executive nominates the judicial appointments and the legislature confirms them. The judiciary interprets the constitution and through its power of judicial review could declare legislative and executive actions unconstitutional. Through these means, they participate in one another's sphere, check and control one another. The independence of the different arms could create antagonism and deadlock in terms of legislative-executive relations. It also makes collaboration, lobbying and cooperation in governmental functions imperative. For example, the Chief Executive must rely on the legislature for legislation, fund, personnel administrative structure, etc.

The result is that the government pro-policy-making-process application is fractured and cannot consistently produce effective action. In the circumstance, cooperation and compromise become the solution of the thorny relationship. As A.D. Roosevelt puts it: "The letter of constitution wisely declared a separation, but the impulse of common purpose declares a union".

\section{Models of Legislative-Executive Relations}

There are two models of legislative-executive relationship, representing two schools of thought. One is the legislative force model, while the second one is called executive force model.

The legislative force or classical model emphasizes the supremacy of the legislature in the scheme of government business. The legislature should have supreme power to formulate and enact policies, and to intervene and control the executive arm subject to constitutional provisions. The legislative is omnipotent and the executive impotent.

This view is reminiscent of legislatures centuries ago, which were seen as the symbol of representative government, and therefore endued with supreme powers to oversee the executive branch on behalf of the people. The authors of the United State Constitution, for example, expected the legislature to be the most powerful arm of government.

It is however, instructive to note that the growth of the executive branch, in the last century and the consequent decline on the legislatures undermines the model. The various factors responsible for the decline of legislative institutions have been discussed elsewhere.

The other school is the executive force model. Exponents of this school of thought place the executive as the most powerful, influential and therefore supreme arm of government. The proper role of the legislature is to accept and respond to the executive leadership. Legislators should, therefore, play minimum role in initiating and formulating 
policies, make only marginal changes in executive bills, and appropriation proposals and consequently possess only minimal (limited) influence over administration. The executive becomes the omnipotent and the legislature impotent.

In the contemporary Nigerian situation, the executive force model tends to be the case. The apparent attempt by the legislature to assert its independence had largely been responsible for the conflicts between the two arms of government. It is important to note as espoused above, that these models attempt to determine who is the superior or more powerful partner in the relationship. It's generally within this paradigm that the typology of legislative-executive relationship emerges.

\section{Types of Legislative-Executive Relationships}

Oyediran (1980), in his study of Nigeria's legislative institutions, distinguished several types of legislative-executive relationships. However, for the purpose of our analysis in this exercise, only three types of relationship will be identified namely: Cooperative, Rubber Stamp and Antagonistic. In the cooperative, there is a considerable endeavour, and this makes for smooth, quick and good government.

In the Rubber Stamp relationship, there is uncritical conformity and excessive support of the executive by the legislature. In other words, the degree of legislative compliance, executive unilateral decisions and post-hoc legislation is high. When this situation occurs in legislative-executive relationship, there are usually three possible interpretations that such could engender. First, when a legislative institution has to work hand-in-hand with a powerful charismatic leader (Executive), the legislators could become chorus singers.

The second possible explanation may be anchored on the degree of educational attainment of members of the legislature. If the law-makers are not well-versed in western education, then it will be possible for the executive to hoodwink them at all times with impunity. The third interpretation may arise in a legislature studied with docile and tractable characters. The fourth explanation, which is the most probable explanation in Nigeria, is what Joseph (1987) called patron-client relationship in Nigeria's body politic. The grid of Nigerian political society is 'an intricate and expanding network of patron-client ties, which serves to link communities in a pyramidal manner. As it is commonly observed, at the apex of such networks are found individual political office-holders at the federal and state levels'. What is very crucial is the exchange of diverse patronage for assistance, support and loyalty among the political class.

Indeed, in contemporary Nigeria, an analysis of legislative-executive relation needs to take cognizance of the 'the spatial as well as vertical dimensions of what can be termed ethnoclientelism'. Without understanding, one cannot grasp the ease with which societal resources were being appropriated by the legislature and executive. Clientelism, and more broadly ethno-clientelism, in which the essential functions or roles to be performed by each are blurred and inconsequential as long as individual or group interests are served.

The issue of patron-client relation seems to be a notable feature in many states in Nigeria. In situation where such exists, one may not expect wonders from the legislators in its control mechanism of the executive. This is because legislators are expected to support their kinsfolk (executive) for patronage and support.

Be that as it may, the type of legislative-executive relationship depends on the approaches adopted by both branches of government, especially the executive. They might choose to be diplomatic and constructive in which case, the motto is communication, conciliation, compromise and cooperation. The chief executive might adopt the horn-like approach, brandishing his veto power, resources and patronage to coerce legislators into support, or he might decide to be aloof or partisan or non-partisan in his approach, depending on his party strength and political relations.

\section{Causes of Conflicts}

Several reasons can be advanced for the legislative-executive face-off, witnessed since the inception of Nigeria's Fourth Republic on May 29, 1999. The remote cause of the conflict can be traced to the pre-colonial cum colonial power relation between the two organs of government. The development of central legislature and the executive can be traced to the annexation of Lagos as a colony in 1861. The legislators so created were theoretically charged with the responsibilities of making laws and ordinances to set up institution 'for peace, order and good government' in the colony. It is instructive to state here that the power of the legislative council was neither absolute nor in conformity with what was obtainable elsewhere. The executive could enact laws such that were considered necessary for the peace, order and good governance of the colony.

The constitutional development of Clifford, McPherson, Lyttleton followed this pattern of subordinate legislative institutions. In the period under review, there was no time in which the legislature had effective control of the executive. In other words, the legislature lacked the power to inquire into or oversee the activities of the executive. For instance, the Nigerian Council between 1914 and 1922 had no legislative authority, because any resolution passed by it was not binding on the executive (the Governor). The power of the legislative council of 1923 was also limited to the southern protectorate. With the constituted legislatures of 1951-54 and 1954-59, there came the opportunity for gradual 
integration of Nigeria's political elite into Westminster (parliamentary) system of government.

However, this integration was more of theory than practice. The executive never allowed the legislators to have free course. The executive occupied the aristocratic position of pre-colonial Nigeria monarchs and the British overlords. Every attempt by the legislature to assert its authority under the constitution is always met with fierce contention of the executive.

The long history of executive domination has been aided by the lack of parliamentary experience of many lawmakers. The post-independence political institutions were marred with series of crises ranging from the position of Northern Nigeria, vis-à-vis other regions in the subsequent call for creation of more states. There were also the problems of revenue allocation, national census, etc. All these culminated in the military coup d'etat of January 15, 1966. The military stayed in power from 1966-1979 and 1983-1999. The implication is that in all these periods of military interregnum, the legislative branches never operated.

In other words, the high turnover of the military coup d'états did not afford the legislature the opportunity to learn and practise politics. Hence, when the legislature was allowed to function, after the ban on politics was lifted, it had to start from the base level. As Oyediran (1990) has aptly said, "however efficient, effective and responsive an institution and its members may be, continuity of existence is very important". The situation became aggravated with the change of government in 1979 from parliamentary democracy to executive presidential system with all its complexity. Both the executive and the legislators have demonstrated their confusion and, in many cases, ignorance of the working of the presidential system. The net result of this is bickering, infighting and slandering of each other as witnessed whenever there is friction between the two arms of government.

The question of political instability in the past has also given rise to absence of democratic attitude. Given the general absence of democratic institutions and rule of law under the military, many people had become extremely militarized over time. Indeed, it will be apposite to assert that the military dictatorial command structure had infected the political space 'to the extent that most citizens become restive, aggressive and militaristic in approach. In actual fact, the matter is being compounded when one considers the fact that two of Nigeria's presidents since 1999 had military background. The two (Obasanjo, 1999-2007 and Buhari, 2015 to date) were Generals in the Nigerian Armed Forces. They had also governed Nigeria under a unified (centralized) military structure. There is a tendency of militarizing the political space. This may in part explain the paternalistic posture of the executive towards the legislature. The Nigerian presidency has since the inception of the fourth republic assumed this fatherly status, hence no principled contradiction is ever tolerated, no matter how constitutional it may be.

In Nigeria's fourth republic, the genesis of the conflicts between the federal legislature as represented by the National Assembly (comprising the House of Representatives and the Senate) and the Executive branch represented by the Presidency can be seen in the tendency of the Executive branch, to intervene in the choice of principal officers of the National Assembly such as the Speaker, Deputy Speaker, President of Senate and Deputy Senate President. It was widely believed that the choice of Alhaji Abubakar Salisu Buhari and Evan Enwerem as Speaker of House of Representatives and Senate President were influenced by the executive. Within a short period of their tenure, there were serious allegations against the two of them. For instance, Salisu Buhari, was said to have been an underage (false age declaration) and also guilty of certificate forgery. The allegation against Evan Enwerem followed a similar pattern of certificate forgery and being an ex-convict. The two of them (Buhari and Enwerem) did not survive the crisis. Indeed, Buhari had to vacate his seat in the House of Representatives. He was roundly convicted and fined. The speed with which President Olusegun Obasanjo gave him (Buhari) presidential pardon thereafter lent credence to the allegation that the President had more than official interest in who becomes the Speaker of the House of Representatives.

The National Assembly replaced Salisu Buhari for Alhaji Ghali Umar Na'Abba, while Senator Chuba Okadigbo replaced Evan Enwerem. Hence, under the leadership of Ghali Na' Abba and Chuba Okadigbo in the National Assembly, there was no love lost between the legislature and the Executive. By February 21, 2002, the House of Representatives under Na'Abba (2004) issued a political blueprint aimed at checkmating the executive influence on the legislature. It set out among others to promote an egalitarian society, improve the quality of life of every Nigerian, create a private sector-driven economy, eliminate corruption, promote public participation in decision making, ensure that no Nigerian is oppressed, defend and uphold the letters and spirit of the Constitution, and promote global peace and harmony. There is no doubt that the political blueprint as espoused by the House of Representatives determined largely the dynamics of the House that gave it character. The issue of furniture allowance was soon employed by the executive as an instrument to blackmail the lawmakers. In the same vein, Chuba Okadigbo, the then Senate President, faced political persecution believed to have been sponsored by the depth of political manoeuvring hanging on his office, as forces opposed to his Senate Presidency drew up a list of complaints against him. It is instructive to note that the two of them ( $\mathrm{Na}^{\prime} \mathrm{Abba}$ and Okadigbo) were later replaced by Alhaji Aminu Bello Masari and Anyim Pius Anyim of House of Representatives and Senate respectively. The high turnover of leadership in the National Assembly has impacted its workings negatively. 
The constitutionally guaranteed checks and balances, and oversight powers of the National Assembly have been variously challenged by the executive as it was oftentimes viewed with trepidation and suspicion from the executive.

However, it appeared that the executive was able to find amiable personalities in Aminu Bello Masari and Anyim Pius Anyim. For Masari (the Speaker of the House of Representatives), he came with a different approach to legislative-executive relation, as he couched his approach as 'constructive cooperation with the executive'. This approach has been variously abused by executive recklessness which never gave 'credence to the constructive engagement as a novel approach capable of goading the president to accord parliament the recognition it deserves in a constitutional democracy that is based on a tripartite system of governance. Good examples of such were the 2004 Appropriation Act, fuel tax, fuel price, etc., in which the legislature was treated with disdain by the executive.

There is also the issue of monetization of politics in Nigeria. The use of money in politics, perhaps, came into the open in the second republic. This later became a more pervasive and disconcerting phenomenon in the military interregnum of 1983-1999. Politics and political transition programs became transformed into lucrative endeavour where people could become rich within a twinkle of an eye. The legislators like the executive too must spend to attract the votes of the electorate. Situations such as this must have largely informed the legislators on the need to recoup their monies invested in electioneering campaigns. This has inevitably led to the proclivity for tampering with the appropriation bill by the National Assembly. It was such that the legislators insisted on very comfortable living and working conditions, which are incompatible with what highest paid public officers earn. Indeed, the alleged colossal expenditure by the National Assembly on contracts and personal emoluments underscores the high level of monetization of the political process in Nigeria. Indeed, Lamido Sanusi Lamido, the former Governor of Central Bank of Nigeria, now deposed Emir of Kano, blamed the economic crisis of Nigeria on the earnings of members of the National Assembly which account for $25 \%$ of the total annual public expenditure.

The two political parties are mere political expressions. This is because they lack ideological and political philosophy with which they can meaningfully discuss, analyze and execute their manifestoes. Indeed, their ideological leaning is supposed to be the basis of their political differences. Many members of these parties are a collectivity of incompatibles, hurriedly formed to contest the transition elections. The ruling party, All Progressives Congress (APC) has not proved significantly to be better than the Peoples' Democratic Party (PDP) that was defeated in the presidential election of 2015 and 2019 presidential elections. The internal bickering between its executive and legislative arms, as represented by Muhammadu Buhari, Bukola Saraki and Yakubu Dogara between 2015-2019 largely disrupted the machinery of national government. While Buhari represents the Executive arm, Saraki and Dogara are the leadership of the Senate and the House of Representatives respectively. Indeed the $8^{\text {th }}$ National Assembly between 2015-2019 was marred by unmitigated acrimony between the Executive and the National Assembly.

The etiology of the crisis of the 8th National Assembly is traceable to the contentious emergence of Senator Bukola Saraki as Senate President and Yakubu Dogara as Speaker of the House of Representatives. The problem became further aggravated when Ike Ekweremadu of PDP was subsequently elected Deputy Senate President. The admixture of the ruling party and opposition at the National Assembly no doubt embarrassed the Buhari presidency as it portended political crises for the ruling party especially in the passage of bills, and the necessary cooperation that the Executive (Presidency) expected from its legislators who commanded comfortable majority at the National Assembly. Hence from the inception of the $8^{\text {th }}$ National Assembly, the Executive could not trust the National Assembly headed by the duo of Sakari and Dogara. This mutual suspicion lingered until the 2019 federal elections. The federal executive blamed its poor performance between 2015-2019 on the competitive politics between the two branches (Executive and Legislature) of government which occasioned the deliberate delay in passing the national budget into law by the National Assembly. Indeed, the Executive and Legislature appear to enjoy the politics of buckpassing and blame games which do not augur well for the generality of the citizenry.

In the political interplay of the period in question, the Senate withheld its power of confirmation of executive nominees into the Central Bank of Nigeria (CBN) -(Deputy Governor and Monetary Policy Committee (MPC) of the CBN); and members of the Code of Conduct Bureau (CCB). The Senate also vehemently refused to confirm Ibrahim Magu as Chairman of the Economic and Financial Crimes Commission (EFCC), ostensibly on the ground of negative intelligence report submitted to it by the Department of State Services (DSS). The DSS had retracted the earlier report on Ibrahim Magu as a mix-up. The Presidency on the other hand, refused to sack or adhere to Senate's recommendation for a fresh nomination. Hence Magu had to perform the functions of his office in an acting capacity.

Perhaps more worrisome in the face-off between the legislature (National Assembly) and the Executive as represented by the Presidency was issue of elections timetable of 2019 general elections. The Independent National Electoral Commission (INEC) fixed the presidential and National Assembly election for Saturday, February 16, 2019 and Governorship and State House of Assembly for March 2, 2019. This arrangement appeared untenable to the National 
Assembly who demanded that the National Assembly elections should precede the presidential poll, in order to avoid what may turn out to be bandwagon effect on the elections of its members. The amendment electoral bill was accordingly sent to the President. In the spirit of the conflict between the two arms of government, the President refused to sign the amendment into law. In a swift reaction, the National Assembly contemplated the option of vetoing the executive power. As the controversy began to trail the reordering of the timetable between the National Assembly and the Executive, INEC was adamant on the application of its own timetable. In the long run, it was the will of INEC that prevailed, but the executive and the legislature had successfully exposed their unfriendly disposition to the public.

It is apposite to add that the political parties lack the institutional control mechanism upon which their members could be molded. The present members of the APC in the Executive and Legislative are an amalgam of previous opposition members and disenchanted members of PDP. APC won the 2015 presidential seat by hurriedly putting together individuals with the sole aim of defeating PDP in the build up to 2015 general elections. The two political parties (APC and PDP) are largely bankrupt of ideology. They are political parties of all-comers. They are never constituted by like minds, hence they lack responsibilities in shaping opinions and setting agenda that can serve as a rallying point for their members. It is no secret that since the formation of APC in 2015, Nigeria's political parties' formation had witnessed two dominant parties of APC and PDP. The rate at which their members cross from one party to the other has not only been embarrassing but shows a perceptible sense of political disintegration of a political system built on divers political ideologies.

\section{Conclusions: Towards Management of Legislative-Executive Conflicts}

It is important to stress from the onset that legislative-executive conflicts are normal process in any democratic situation. Indeed, agreements and disagreements are two sides of democracy and they are necessary if the polity must advance from the medieval era.

One area that has to be tackled is the constitution itself. From all indications, it seems that most of the operators of the Nigerian statecraft do not understand the constitution. First, it must be realized, that the 1999 Constitution, with all its 'imperfections' is supreme and its provisions are binding on all authorities, institutions and individuals throughout the length and breadth of the country. The said constitution has specific provisions on the functions and powers of the legislature and the executive. For instance, it states that the legislative power is vested in the combined House of Representatives and Senate otherwise known as National Assembly. In summary the National Assembly is to make law for 'peace, order and good government of Federation'.

The executive power, on the other hand, is vested in the Governor, President and such can be delegated to members of the cabinet, such as commissioners, ministers etc. At the federal level, the president is responsible for the execution and maintenance of law and order. The legislature exercises its powers through bills passed by both Houses as assented by the executive (President) within thirty days. Should the President withhold his assent, the two Houses with two-thirds majority each could pass such bill into law. In the case of electoral law, the constitution empowers the INEC to administer the elections of the State House of Assembly, Federal House of Representatives, Senate, Governor and President. The question is whether the National Assembly has the power to alter the election timetable as fixed by INEC. This is for the Judiciary to determine, hence it's for either of them to approach the Judiciary for interpretation and determination as appropriate.

In terms of the Appropriation Bill, it is the duty and responsibility of the executive to lay the bill before the National Assembly. But in situations where both Houses refuse to pass the bill within two months into a financial year, the President can operate on the previous budget for six months pending the operationalization of the Appropriation Act. An appropriate understanding of the constitution by both arms of government, will lead to the realization of the goals set in chapter iii otherwise known as fundamental objectives and principles of state policy. We believe it is lack of perception and understanding of their roles and responsibilities that has given rise to conflicts between the two arms of government. The legislature for instance, has no business with executing projects or having to share budgets appropriated to it; hence the idea of constituents projects allowance appropriated to legislators should be discouraged forthwith.

The legislators' penchant for comfortability at the expense of the masses they are representing need to be addressed. In an ideal situation, their standard of living is supposed to be a reflection of the society at large. It is instructive to note that it was in pursuit of their own conveniences that they fell headlong with the executive determined to execute anti-corruption bill.

The first step towards anti-corruption crusade is to de-monetize political offices. The perquisites of office and monetary remuneration of public office holders are too excessive compared with other Nigerians in the other sectors. This has constituted the elected office holders as a special breed. In the extreme, the National Assembly members have alienated themselves from the people they are supposed to represent at the center; hence the whole essence of representative democracy has been defeated by bogus living standard of the political class. 
There is the need to de-radicalize the executive and the legislative. The two arms have to adopt flexibility and the spirit of give and take. They must adhere strictly to the principle of the rule of law, public accountability and financial transparency.

It is apposite to conclude on the note of optimism that the political future of Nigeria is bright once we can solve the constitutional issue and provide enabling space for legislative-executive relations -- a strong constitutional base (foundation) that would ensure the survival of the Nigerian political institutions. There is the need for constitutional re-engineering to strengthen our institutions such as the Presidency, Legislative, INEC, EFCC, ICPC, etc., as opposed to strengthening individuals. If the institution is empowered with weak political leadership, the system will sustain the statecraft.

Finally, conflicts and conflict resolution are the hallmark of democracy. Whenever they emerge or surface, they must be resolved within the confines and dictates of the constitution. This is the essence of constitutional democracy.

\section{References}

Anthony J. E. et.al. (1995). American Democracy Representation, Participation and the Future of the Republic (New Jersey, Prentice Hall, Eaglewood Cliff). Journal of Parliamentary Affairs, xvii, Winter 1963/64, p. 69.

Awotokun, K. (2020). The Legislative and Executive institutions and the challenge of Governance in Contemporary Nigeria (forthcoming). https://doi.org/10.5539/jpl.v14n2p19

Awotokun, K. (2020). The Nigeria's Presidentialism and the Burden of Profligacy in an Inchoate Constitutional Democracy. Mediterranean Journal of Social Sciences (MJSS), 11(5). https://doi.org/10.36941/mjss-2020-0053

Awotokun, K., \& Okotoni, O. (2019). Governance and Executive-Legislative Relations Since Nigeria's Fourth Republic (1999-2019) and Beyond, Public Administration Research, Canadian Center of Social and Education, 9(2). https://doi.org/10.5539/par.v9n2p28

Ekpu, A. (2017). Powers of the Executive and Legislature in Budget making Process in Nigeria: An overview. Journal of Law, Policy and Globalization, 57.

Federal Republic of Nigeria, The 1999 Constitution of The Federal Republic of Nigeria, Secs. 4(1) (2)(8).

Federal Republic of Nigeria. (2011). The Constitution of 1999 of the Federal Republic of Nigeria, Fundamental Rights, Rules with Amendments.

Ibid., Friday, February 23, 2001.

Ibid., Sec. 58.

Ihemeje, C. C. et.al (2016). Factors influencing the Executive and Legislative Conflict in Nigeria Political Development IOSR. Journal of Humanities and Social Sciences, 21(8). https://doi.org/10.9790/0837-2108072025

Kunle, A. (1996). 'Towards an Effective Legislative Control of the Executive in Nigeria', Nigerian Journal of Public Administration and Local Government, vii(I).

Kunle, A. (1998). Governance and Legislature Control in Nigeria: Lessons From the Second and Third Republics, San Francisco, International Scholars Publications.

Kunle, A. (2012). Nigeria's Democracy and the Crisis of Political Leadership: Legislature versus Executive. In W. Bokelman et.al. (eds). African Leadership Challenges and Other Issues Media Team, IT Educational Publishers Berlin Germany.

Obasanjo, O. (2014). My Watch, Vol. 3, Lagos, Kachifo Ltd.

Obidimma, A. et.al (2015). 'The Legislative-Executive Relations in Nigeria's Presidential Democracy', International Journal of Business and Law Research, 3(1).

Olusegun, O. (2001). Party Discipline is an Instrument of National Stability. The Comet, Lagos.

Oye, O. (1980). Nigerian Legislature Houses - Which Way? Ibadan, Ibadan Consultancy Unit. Tell, Nigeria's Independent Weekly Magazine, Lagos, March 26, 2001 p.28.

The Comet. (2001). Lagos.

The Nation. (2018). Cost of Unending Executive-Legislative Standoff.

\section{Copyrights}

Copyright for this article is retained by the author(s), with first publication rights granted to the journal.

This is an open-access article distributed under the terms and conditions of the Creative Commons Attribution license which permits unrestricted use, distribution, and reproduction in any medium, provided the original work is properly cited. 